International Scientific Journal Theoretical \& Applied Science

p-ISSN: 2308-4944 (print) e-ISSN: 2409-0085 (online)

Year: 2017 Issue: 11 Volume: 55

Published: $16.11 .2017 \quad \underline{\text { http://T-Science.org }}$

SECTION 31: Economic researches, finance, innovations, risk management.

\section{Anna Vyacheslavovna Golovko \\ undergraduate, \\ Institute of Entrepreneurship and Service sector (branch) DSTU, g. Shakhty}

Vladimir Timofeevich Prohorov Doctor of technical sciences, professor, Institute of Entrepreneurship and Service sector (branch) DSTU, g. Shakhty

Igor Pavlovich Guschin undergraduate,

Don State Technical University, Rostov-on-Don

\title{
ABOUT OPPORTUNITIES OF PARTISIPATIVNY MANAGEMENT IN THE FIELD OF QUALITY WITHIN A QUALITY MANAGEMENT SYSTEM FOR PRODUCTION OF DEMANDED PRODUCTION
}

Abstract: The article authors analyze possibilities of policy and the purpose of the enterprise in the field of quality within SMK to fight for faultless production, decrease in marriage and guarantees to consumers high quality of the made production. The efficiency and effectiveness of the policy developed by authors and the purposes in area of quality within SMK for ensuring faultless production with essential decrease in release of the rejected production have allowed to present use of the chart of Pareto visually.

Key words: quality management system, certification, compliance confirmation, metrology, standardization, audit, voluntary confirmation, obligatory confirmation, demand, chart of Pareto, politician, purpose, documentation, effectiveness, efficiency, reliability, interest, responsibility, produktion.

Language: Russian

Citation: Golovko AV, Prohorov VT, Guschin IP (2017) ABOUT OPPORTUNITIES OF PARTISIPATIVNY MANAGEMENT IN THE FIELD OF QUALITY WITHIN A QUALITY MANAGEMENT SYSTEM FOR PRODUCTION OF DEMANDED PRODUCTION. ISJ Theoretical \& Applied Science, 11 (55): 50-68.

Soi: http://s-o-i.org/1.1/TAS-11-55-9 Doi: crossef https://dx.doi.org/10.15863/TAS.2017.11.55.9

UDC 335.17:519.78.

\section{О ВОЗМОЖНОСТЯХ ПАРТИСИПАТИВНОГО УПРАВЛЕНИЯ В ОБЛАСТИ КАЧЕСТВА В РАМКАХ СМК ДЛЯ ПРОИЗВОДСТВА ВОСТРЕБОВАННОЙ ПРОДУКЦИИ}

Аннотация: В статье авторы анализируют возможности политики и цели предприятия в области качества в рамках СМК для того чтобы бороться за бездефектное производство, снижение брака и гарантирует потребителям высокое качество изготавливаемой продукиии. Использование диаграммы Парето позволили наглядно представить эффективность и результативность разработанной авторами политики и изелей в области качества в рамках СМК для обеспечения бездефектного производства с существенным снижением выпуска бракованной продукции.

Ключевые слова: СМК, сертификация, подтверждение соответствия, метрология, стандартизация, аудит, добровольное подтверждение, обязательное подтверждение, спрос, диаграмма Парето, политика, цели, документация, результативность, эффективность, достоверность, заинтересованность, ответственность.

\section{Introduction}

Выбор предприятий машиностроения в качестве объекта для оценки эффективности социально - психологического фактора при внедрении СМК обусловлен тем, что эти предприятия характеризуются наличием высококвалифицированных рабочих и специалистов. Таким образом, Политика целей и задач СМК будет реализовываться значительно эффективнее и с меньшими затратами за счет трех главных аспектов: вовлечение работников, процессный подход и системный подход. Коме того, персонал предприятий машиностроения эффективнее способен реализовать цели и задачи СМК еще и потому, что эффективнее обеспечивается контрольная деятельность по 
выполнению следующих ситуаций: убеждение, исполнение делегированных полномочий, создание условий для повышения производительного труда и эффективного использования деловых качеств сотрудников.

Необходимость совершенствования системы менеджмента качества на предприятиях машиностроения обусловлено следующими важными причинами. Во-первых, это повышение доверия потенциальных потребителей к продукции, которую выпускает данное предприятие. Во-вторых, это возможность значительно укрепить свое положение на уже существующих рынках, а также значительно расширить сферы влияния путем выхода на новые отечественные и зарубежные рынки. И втретьих - это значительное повышение производительности труда любого промышленного предприятия на котором предполагается внедрение СМК, с использованием партисипативного управления.

В настоящее время в организациях большое значение уделяют мотивации сотрудников, так как в зависимости от того, насколько сотрудник мотивирован, будут видны и результаты его деятельности. Основной задачей менеджеров становится полное задействование в работе всего потенциала сотрудников. Причем менеджеры понимают, что материальное стимулирование не повышает лояльность и приверженность компании. Партисипативное управление решает этупроблему.

Суть такого управления состоит в том, что при нем сотрудники организации включаются в процесс управления, участвуют в деятельности компании, принимают решения по ряду вопросов. Причем если сотрудник фирмы имеет право голоса, принимает участие в деятельности организации, получая за это вознаграждение, тогда он будет работать более качественно и производительно. Сотрудник, с мнением которого считаются, идеи которого внедряются, будет лучше относиться к месту своей работы и будет работать с полной отдачей.

\section{Materials and Methods}

При партисипативном управлении сотрудники могут обговаривать с руководителем цели и задачи, которые ему будет необходимо выполнить. Сотрудники организации могут сформировать рабочие группы из тех сотрудников, с которыми им было бы приятно и комфортно работать. Помимо этого сотрудники организации могут выдвигать свои идеи и предложения по поводу усовершенствования работы компании в целом. Причем за выдвижение идей должно идти и вознаграждение.
Партисипативное управление имеет ряд преимуществ. Участие в управлении сотрудников приводит к повышению качества принимаемых решений, поскольку работники могут обладать той информацией, которая не известна руководителю. При таком управлении сотрудники могут проявить в полной мере себя, показать свои знания и умения, а также почувствовать свою значимость в организации, таким образом повышая мотивацию. В основе мотивации обычно присутствуют не только личные достижения сотрудника, но и общий результат работы фирмы. Объединение сотрудников по рабочим группам наилучшим образом может отразиться на корпоративном духекомпании.

Тем не менее, партисипативный подход помимо преимуществ имеет и свои недостатки. Не все люди в силу своего характера готовы участвовать в управлении организацией и выдвигать идеи и предложения, неся за них ответственность. Многим сотрудникам гораздо проще выполнять работу по указанию руководителя. Привлечение работников к управлению в организации может не лучшим образом отразиться на менеджерах, так как они могут потерять свое влияние на сотрудников. Много времени также будет уходить на обсуждение проблем, при этом однозначного решения может быть и не принято, а времени потрачено. Многие идеи и предложения сотрудников компании могут быть нерациональными и неуместными в силу недостаточности знаний. Поэтому руководителям фирмы необходимо информировать сотрудников о положении дел в компании, обучать персонал с целью углубления знаний и выдвижения более эффективных и актуальных предложений. Отсутствие признания идеи работника может вызвать неоднозначную реакцию у сотрудника, выдвигающего свои инновационные предложения, тем самым демотивируяего. Поэтому руководителям организации необходимо объяснять, почему данная идея не подходит в той или иной ситуации.

Рассмотрев все плюсы и минусы партисипативного управления, можно сделать вывод, что такое управление не является спасательным средством для улучшения дел в организации, но оно позволяет увидеть проблемы организации изнутри и попытаться решить их не усилиями одного человека, а группой лиц, где каждый сможет проявить себя на благо организации.

Независимо от того, что партисипативный метод управления кадрами организации получает с каждым годом все большее одобрение в большинстве стран с развитой и развивающейся экономикой, российские 
организации пока не готовы внедрить и полностью осознать преимущества этого метода. Все это потому, что службы управления кадрами предпочитают работать по сложившейся традиционной схеме.

Большая часть российских предприятий, как долго действующих, так и недавно созданных, использует директивный метод управления. На таких предприятиях управленческие решения принимаются единолично, рост по карьерной лестнице идет за счет «хороших связей» с руководителем, а не собственных заслуг в работе, частые нарушения трудового законодательства являются обычным делом. Причиной, по которой отдается предпочтение директивному методу, является сложившийся на протяжении многих веков национальный менталитет нашей страны, а также присутствующая до сих пор советская идеология во многих компаниях. Вследствие этого, менеджмент на таких предприятиях централизован, административен и носит характерформальности.

$\mathrm{He}$ более половины менеджеров по управлению персоналом могут достичь и умело использовать согласованность поставленных целей с возможностями предприятия и интересами сотрудников.

Еще одним очень важным фактором, не позволяющим принять парситипативный метод управления персонала на российские предприятия, можно принять влияние национальной культуры России. От этого влияния зависит выбор стратегии управлением кадровыми ресурсами в практической деятельности организации.

К культурной особенности российских предпринимателей, по мнению большинства исследователей, использовавших системный подход при определении, относится зависимость от коллектива и сформированных им нормам поведения, стремление к доверительным отношениям, уход от ответственности. Часто отдается предпочтение личным качествам сотрудника, чем его успех в выполненной работе, происходит смешивание личных и деловых отношений. Также нашей российской действительностью замечена склонность предпринимателей и их сотрудников к подкупу, скрытие доходов от налоговой службы, подделка документов, пренебрежение к этическим нормам по отношению к конкурентам. Между руководителем и сотрудником проявляется разрыв в общении, по-другому можно сказать, что руководитель компании недоступен для работников низшего звена. Замечено также, что россияне имеют средний уровень индивидуальности и часто стараются обойти от неопределенности.
Вследствие всего вышесказанного, напрашивается вывод о том, что в России организация и руководство управления персоналом сформировано неэффективно и рабочие коллективные связи практически отсутствуют. Компании уделяют все свое внимание на выполнение условий, которые поставил перед ними государственный бюрократический аппарат, а не на выполнение ответственности перед потребителями иобществом. Поэтому возникает трудность внедрения «западных» методов управления в российскую практику.

Для того чтобы наиболее успешно внедрить парситипативное управление кадрами и подготовить сотрудников к изменению подхода работы в коллективе, прежде всего необходимо установить меры по поощрению индивидуальности в каждом работнике компании и устранить устоявшуюся недоступность руководителя для низшего звена. Важно создать качественную и действующую систему мотивации и постоянное повышение квалификации, чтобы персонал стал источником конкурентоспособности компании, соответствовал современным требованиям к управлению человеческими ресурсами.

Руководство по качеству направлено на применение «процессного подхода» при разработке, внедрении и улучшении результативности системы менеджмента качества c целью повышения удовлетворенности потребителей путем выполнения их требований.

Преимущество процессного подхода состоит в непрерывности управления, которое он обеспечивает на стыке отдельных процессов в рамках системы, а также при их комбинации и взаимодействии.

Основными процессами системы менеджмента качества являются:

$\square$ проектирование и разработка продукции;

$\square$ составление плана производства;

$\square$ производство

$\square$ контроль и проведение испытаний продукции;

$\square$ упаковка и хранение продукции;

$\square$ продажа;

$\square$ закупки;

$\square$ обеспечение ресурсами;

$\square$ проведение

маркетинговых исследований.

Виды деятельности по измерению и мониторингу для обеспечения и верификации соответствия продукции определены в комплексной документации, производственных планах и сменных заданиях, технологических процессах, процедурах по измерению, анализу и улучшению.

Деятельность по мониторингу, измерениям, 
анализу и улучшению включает в себя: исследование удовлетворенности потребителей;

$$
\text { внутренний аудит; }
$$

мониторинг и измерение процессов; мониторинг и измерение продукции; управление несоответствующей продукцией;

непрерывное улучшение, в том числе корректирующие и предупреждающие действия;

определение мест применения инженерных и статистических методов.

Проявившийся полученный в сфере реализации поршнях или в процессе материалов использования продукции составят брак, свидетельствует не только о плохом дефектам качестве продукции, но и о неудовлетворительной работе предприятия.

Коллектив рабочих и служащих совместно с руководством АО «Шахтинский завод Гидропривод» приняли коллективное решение по разработке и внедрению СМК, а также по постоянному повышению ее результативности и эффективности. Эти цели и задачи будут реализованы в виде политики и целей предприятия в области качества .в 2017 году, для чего были сформулировали цели в области качества. Политика и Цели в области качества были составлены в соответствии с производственными целями предприятия, документально оформлены и доведены до всех рабочих и служащих предприятия с необходимыми разъяснениями и постановкой конкретных задач перед персоналом и утверждением их приказом. Так как потери за 2016 год составили 16167620 рублей, руководство предприятия, было заинтересовано в реализации спланированных мероприятий, чтобы обеспечить бездефектное производство и улучшение качества продукции.

Учитывая, что бракованные изделия не подлежат восстановлению и ремонту, конструкторским бюро было предложено руководству предприятия их утилизировать, а полученный металл повторно использовать для производства новых изделий, что они и стали делать. Общая масса металла, полученная за счет утилизации бракованных деталей в 2016 году, оказалась равной произведению количества бракованных насосов - 473шт., на средневзвешенную массу одного насоса, которая равна 38 кг, а именно:

$$
\mathrm{m}=473 \cdot 38=17974 \text { кг }
$$

Затраты на утилизацию складывались из электроэнергии( 23 рубля .на 1 кг), зарплата рабочим(13 руб. на 1 кг), а амортизационных отчислений за счет использования оборудования составило 76 руб. на 1 кг, то есть всего:
$\mathrm{C}=(76+13+23) \cdot 17974=2013088$ рублей

С учетом договорных цен на металл, после их переплавки предприятием было получено: (договорная стоимость 1 кг металла-350 рублей) 6290900 рублей.

Возврат денег предприятию в 2017 году за счет утилизации бракованных изделий с учетом затрат составил

$$
Э_{\text {уб }}=6290900-2013088=4277812 \text { рублей. }
$$

Годовой объем реализации с вычетом потерь за 2016 год составил

$$
\begin{gathered}
\mathrm{O}_{\mathrm{P}}=15541148100-16167620+4277812= \\
1542258292 \text { рублей }
\end{gathered}
$$

Такой результат стал возможным за счет использования партисипативного управления реализации Политики и целей в области качества и процедур, разработанных руководством предприятия в рамках системы менеджмента качества, формирующие требования ко всем участникам процесса по созданию условий на предприятии для производства бездефектной продукции и при жестком контроле их выполнения.

1.Руководство по качеству. Является основополагающим документом системы менеджмента. Руководство по качеству описывает структуру и содержание системы менеджмента качества, направленную на обеспечение соответствия продукции требованиям потребителя и обязательным требованиям нормативной документации (НД), а также излагает Процедуры (или дает ссылки на них), разработанные в рамках СМК, описывает взаимодействие между процессами системы менеджмента качества.

2.Внутренний аудит системы менеджмента качества. Настоящая процедура является обязательной документированной процедурой, которая устанавливает порядок и последовательность действий при проведении внутренних аудитов (проверок) системы менеджмента качества.

3. «Гарантийный ремонт продукции»Настоящий документ описывает процесс «Гарантийный ремонт продукции» и устанавливает порядок работы с претензиями потребителей.

4.Управление документацией и записями. Управляемыми считаются документы, подготовка, идентификация, рассмотрение, согласование, распределение, хранение и пересмотр которых осуществляется на основе заранее установленных, систематически используемых правил.

5.Управление несоответствующей продукцией.Настоящий документ является обязательной документированной процедурой, которая устанавливает: а) конкретные обязанности структурных подразделений, 
должностных лиц и отдельных исполнителей по управлению несоответствующей продукцией; б) цели, задачи, сроки, порядок оформления и регистрации записей и документов по управлению несоответствующей продукцией в основном и вспомогательном производстве;

6.Организация контроля качества.Настоящий документ устанавливает: а) порядок организации контроля качества продукции на предприятии; б) конкретные обязанности должностных лиц и отдельных исполнителей по контролю качества продукции предприятия, управлению и идентификации несоответствующей продукции.

7.Закупки. Настоящая процедура устанавливает порядок работы в области оценки и выбора поставщиков, ведения анкеты по поставщикам и определения категории надежности поставщика, определяет единый порядок проведения закупок комплектующих изделий, материалов и полуфабрикатов, их складирования, обеспечения производства и гарантийного обслуживания продукции.

8.Проектирование, разработка продукции и постановка на серийное производство. Настоящий документ устанавливает порядок выполнения процесса «Проектирование, разработка продукции и постановка на производство » и предназначен для: а) регламентации и управления деятельностью подразделения по проектированию и разработке новых видов продукции; б) постоянного улучшения системы менеджмента качества и результатов процесса.

9.Производство продукции.Настоящий документ устанавливает порядок выполнения процесса «Производство продукции» и предназначен для регламентации и управления деятельностью подразделений по производству продукции.

10.Удовлетворенность потребителей.Для определения динамики удовлетворенности потребителя менеджер СМК собирает и систематизирует данные из информационных источников. Источниками информации об удовлетворенности потребителей являются: анкета оценки удовлетворенности потребителя; отзывы потребителей; объемы выпускаемой продукции; объемы отгруженной продукции; премии, награды и дипломы.

11.Технологическая

подготовка производства.Настоящий документ устанавливает порядок выполнения процесса «Технологическая подготовка производства» и предназначен для: а) для регламентации и управления деятельностью подразделения по технологической подготовке производства новых видов продукции. б) постоянного улучшения системы менеджмента качества и результатов процесса.
12. Организация и порядок проведения «Дней качества». «День качества» - это оперативное совещание руководителей структурных подразделений, посвященное контролю и анализу качества работы предприятия и его подразделений.

13.Статистические методы управления качеством.Статистический контроль качества продукции является элементом механизма управления качеством продукции и регулирования взаимоотошений между поставщиком и потребителем, при этом проверка группы или партии изделий осуществляется до и после процесса, а не по ходу процесса.

Главная цель применения статистических методов - регулирование процесса создания изделия высокого качества на всех стадиях от маркетинга до технического обслуживания с меньшими экономическими затратами и высокой эффективностью.

Статистические методы предусматривают сбор, систематизацию и математическую обработку результатов производственной деятельности, анализ информации для принятия корректирующих и предупреждающих мер, дальнейшее исследование объекта контроля для достижения приемлемого (оптимального) уровня качества.

Внедрение системы качества представляет собой комплекс работ, который затрагивает различные аспекты деятельности организации и ее подсистемы - подсистему стратегического управления, производственную подсистему, подсистему логистики, управление персоналом, внутренние коммуникации, документооборот и др. В связи с этим, внедрение системы качества является достаточно трудной, длительной и трудоемкой задачей. Решение этой задачи, как правило, происходит в несколько этапов.

Основные этапы внедрения СМК следующие:

Совершенствование СМК имеет смысл, только в том случае если у коллектива предприятия есть желание добиться весомых результатов в борьбе за качество своей продукции, но все это должно провоцировать желание коллектива достичь новых высот, двигаться вперед и гарантировать себе и своему предприятию стабильные результаты своей деятельности.

Для реализации сформулированных процедур пожеланий должны быть выполнены следующие мероприятия, а именно:

*шаг 1 - осознание высшим руководством иели создания и внедрения СМК на предприятии;

*шаг 2 - установление потребностей $и$ ожиданий потребителей $u$ других заинтересованных сторон; 


\begin{tabular}{|c|c|c|c|c|c|c|}
\hline Impact Factor: & $\begin{array}{l}\text { ISRA (India) } \\
\text { ISI (Dubai, UAE } \\
\text { GIF (Australia) } \\
\text { JIF }\end{array}$ & $\begin{array}{l}=1.344 \\
=0.829 \\
=0.564 \\
=1.500\end{array}$ & $\begin{array}{l}\text { SIS (USA) } \\
\text { PИНЦ (Russia } \\
\text { ESJI (KZ) } \\
\text { SJIF (Morocco }\end{array}$ & $\begin{aligned}= & 0.912 \\
= & 0.207 \\
= & 3.860 \\
= & 2.031\end{aligned}$ & $\begin{array}{l}\text { ICV (Poland) } \\
\text { PIF (India) } \\
\text { IBI (India) }\end{array}$ & $\begin{array}{l}=6.630 \\
=1.940 \\
=4.260\end{array}$ \\
\hline
\end{tabular}

*шаг 3 - формирование стратегии управления, Политики и Целей в области качества;

* маг 4 - организация обучения в области качества всех сотрудников; CMK;

* маг 5 - планирование работ по внедрению

* маг 6-внедрение СМК с формированием команды, состоящей из различных специалистов;

* маг 7 - установление системы процессов, их согласованной взаимосвязи и взаимодействия, выделение ключевых прочессов, необходимых для достижения цуелей в области качества;

* шаг 8- документирование СМК (в том объеме и степени конкретизации, необходимом именно для вамей организации - не забывая об обязательности некоторой документации в соответствии с требованиями ИСО 9001-2015);

* иаг 9 - внутренние аудить;

* маг 10 - доработка документации СМК и устранение замечаний по результатам внутренних аудитов и отработки при внедрении в действие разработанной нормативной документаичи;

* маг 11 - сертификаичя СМК

* маг 12 - дальнейшее развитие СМК.

АО «Шахтинский завод Гидропривод» определило и осуществляет менеджмент многочисленных взаимосвязанных видов деятельности. Процедуры были идентифицированы, описаны и задокументированы.

Кроме того, АО «Шахтинский завод Гидропривод» разработало, задокументировало, внедрило и поддерживает в рабочем состоянии систему менеджмента качества, что обеспечило ему постоянно улучшение его результативности в соответствии с требованиями ГОСТ Р ИСО 9001: 2015.

Таки процедурами в рамках системы менеджмента качества являются:

Основные процедуры:

* проектирование, разработка, изготовление опытных образцов и постановка на серийное производство ГП $08-01$;

* составление плана производства ГП 03-01;

* контроль и проведение испытаний продукции.

* упаковка и хранение (производится согласно типовых и индивидуальных технологических процессов на каждое изделие);

^ продажа (Процесс осуществляет ООО

«Торговый Дом Гидропривод»;

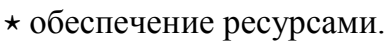

Процедуры менеджмента:

^ процессы управленческой деятельности руководства;

* проведение маркетинговых исследований; АО «Шахтинский завод Гидропривод»:
* определило последовательность и взаимодействие процессов;

* определило для каждой процедуры критерии и методы, необходимые для обеспечения результативности, как при осуществлении, так и при управлении этими процедурами.

Порядок выбора критериев изложен в ГП 01 01 «Порядок разработки, оформления, согласования и утверждения процессов системы менеджмента качества» и предполагает:

*обеспечивать для каждого процесса наличие ресурсов и информации, необходимых для поддержки этих процессов и их мониторинга;

* осуществлять мониторинг, измерение и анализ этих процессов;

* принимать меры, необходимые для достижения запланированных результатов и постоянного улучшения этих процессов.

Переданные ООО «Торговый Дом Гидропривод» процессы обеспечены управлением: в части маркетинга-это совместное участие в выставках, выдача задания на проведение рекламы и исследования тенденций рынка, в части продажи- это договор на реализацию продукции.

Результаты разработки, документирования и внедрения системы менеджмента качества подтверждаются внутренним аудитом (ГП 13-03), проводимым по программе аудита 2 раз в год.

Внутренние аудиты СМК на предприятии проводятся с целью:

* проверки соответствия СМК АО «ШЗГ» требованиям ISO 9001:2008 (ГОСТ Р ИСО 90012015);

夫оценки соответствия СМК требованиям, установленным внутренней документацией АО «ШЗГ»;

^оценки способности СМК к результативному и эффективному функционированию;

* проверки выполнения и результативности корректирующих и предупреждающих действий по несоответствиям, выявленным при проведении предыдущих аудитов;

* определения областей деятельности для улучшения, возможности и путей совершенствования СМК. Внутренние аудиты (проверки) проводятся:

* плановый аудит - 2 раза в год согласно программе проведения внутреннего аудита СМК, утвержденной вместе с приказом о проведении внутренних аудитов Управляющим «АО «ШЗГ».

* внеплановый аудит - основанием для него служит:

* увеличение количества замечаний или рекламаций на выпускаемую продукцию;

* ухудшение качества выпускаемой продукции;

ISPC Technological development, 
* проверка реализации корректирующих и предупреждающих действий и оценки их эффективности;

* изменения структуры управления предприятием;

* необходимость совершенствования процедур, процессов СМК предприятия;

* иные причины.

Аудиты может проводить как менеджер по СМК, так и другие работники предприятия.

Подбор группы по аудиту осуществляет заместитель исполнительного директора по качеству с учетом необходимости обеспечения независимости аудиторов от проверяемой деятельности; или иных факторов, способных оказать влияние на результативность и эффективность внутреннего аудита СМК.

Главный аудитор с группой по аудиту в ходе проведения внутреннего аудита СМК осуществляют сбор информации с целью проверки соответствия СМК требованиям международного стандарта ГОСТ Р ИСО 9001:2015, выполнения требований потребителя и требований документов СМК, результативности и эффективности внедрения записей и поддержания их в рабочем состоянии, знания и понимания Политики и Целей предприятий в области качества, степень достижения целей в области качества, определения возможности улучшения СМК.

Методы сбора информации включают:

^ опрос должностных лиц;

^ наблюдение за производственной средой;
^ анализ документаци

Информация, выявленная в процессе внутреннего аудита СМК, фиксируется аудиторами.

По окончании аудита главный аудитор составляет отчет по внутреннему аудиту СМК. Отчет должен содержать полную, точную и однозначно понимаемую информацию по проведенному аудиту. Этот отчет является одним из видов записей по качеству и необходим для оценки СМК и принятия решений об ее улучшении. Копии отчета направляются руководителям структурных подразделений и высшему руководству.

АО «ШЗГ» планирует и проводит проверки системы менеджмента качества в соответствии с ГП 13-03 «Внутренний аудит системы менеджмента качества»

Высшее руководство ежеквартально анализирует систему менеджмента качества с целью обеспечения ее постоянной пригодности, адекватности и результативности. В анализ включается оценка возможностей улучшения и потребности в изменениях в системе менеджмента качества организации, в том числе в Политике и целях в области качества.

На АО «Шахтинский завод Гидропривод» руководство по качеству является основным определяющим документом системы менеджмента качества и описывающим ее в соответствии с требованиями ГОСТ Р ИСО 9001: 2015.

Общие требования к продукции в части установления технических параметров, санитарных норм и техники безопасности определяются ГОСТ РФ, а на каждое изделие разработаны и утверждены в установленном порядке технические условия, где определены конкретные значения рабочих параметров гидронасоса.

АО «Шахтинский завод Гидропривод» определило и осуществляет менеджмент многочисленных взаимосвязанных видов деятельности. Деятельность, использующая ресурсы и управляемая с целью преобразования входов в выходы, рассматривается как процесс.

Преимущество процессного подхода состоит в непрерывности управления, которое он обеспечивает на стыке отдельных процессов в рамках системы, а также при их комбинации и взаимодействии.

АО «Шахтинский завод Гидропривод», будучи заинтересовано в постоянном улучшении качества производимой продукции, осуществляет планирование и реализацию необходимых процессов проверки, анализа и улучшения.

Данные, свидетельствующие об удовлетворении интересов и требований потребителей в области конструктивных особенностей, изучает конструкторский отдел. Источниками получения таких данных является переписка, служба маркетинга ООО «Торговый Дом Гидропривод» и службы качества.

Целью исследования мнения потребителей является определение степени их удовлетворенности выпускаемой продукции и принятия решения и мероприятия по ее повышению.

Уровень удовлетворенности потребителей качеством выпускаемой продукции является важным критерием результативности СМК и партисипативного управления.

Удовлетворенность потребителей измеряется путем сбора и анализа соответствующей информации, включая обратную связь с потребителем.

По результатам измерения удовлетворенности потребителей оформляется, а отчет по Анализу СМК со стороны высшего руководства.

Претензии потребителей, как восприятие неудовлетворенности, собирают и обрабатывают в службе маркетинга и служба качества.

Сбор пожеланий осуществляют: 
* путем сбора информации от потребителей;

*обеспечение потребителей информацией о новых достижениях в области повышения качества продукции с помощью рассылки рекламных проспектов и информационных листов;

* участия в выставках (ярмарках).

На заводе проводятся внутренние аудиты не реже 2раза в год с целью установления того, что система менеджмента качества:

* соответствует ли требованиям ГОСТР ИСО 9001:2015;

* эффективно ли действует СМК.

Программа аудитов планируется с учетом статуса и важности процессов и участников, подлежащих аудиту, а также результатов предыдущих аудитов. Критерии, область применения, частота и методы аудитов определены ГП 13 - 03. Выбор аудиторов обеспечивает объективность и беспристрастность процесса аудита. Аудиторы не проверяют свою собственную работу. Руководство, ответственное за проверяемые области деятельности, должно обеспечивать, чтобы действия предпринимались без излишней отсрочки для устранения обнаруженных несоответствий и вызвавших их причин. Последующие действия должны включать верификацию предпринятых мер и отчет о результатах верификации.

На АO «Шахтинском заводе Гидропривод» применяются методы контроля и, где это целесообразно, измерения процессов системы менеджмента качества. Целью деятельности по мониторингу и измерениям процессов является:

* проверка соблюдения требований, предъявляемым к процессам (ГП $01-01)$;

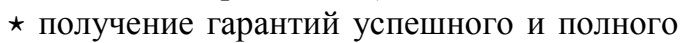
осуществления запланированных действий;

* получение данных для анализа и поиска путей улучшения процессов в СМК в целом.

Деятельность по мониторингу и измерениям процессов СМК распространяется на систему действий по сбору и анализу информации по функционированию процессов СМК, а также на все подразделения завода, участвующие в их реализации.

Ответственность за функционирование и постоянное улучшения деятельности по мониторингу и измерениям процессов возлагается на Представителя высшего руководства СМК. Мониторинг и измерение функционирования процессов СМК проводят их владельцы с использованием подчиненного персонала, технических средств, соответствующих процедур сбора, накопления, передачи и анализа информации, в зависимости от конкретного процесса.

Мониторинг и измерение характеристик продукции с целью сверки соблюдения требований к продукции. Это осуществляется на соответствующих этапах процесса жизненного цикла продукции.

Параметры измерения продукции определяет конструкторский отдел на основании технических условий и выдает задание на разработку стендов для испытания продукции.

Метрологическая служба на основании Положения о метрологической службе проводит метрологическую экспертизу выбранному методу измерения и приборов, на основании показаний которых получают объективные свидетельства качества произведенной продукции. На участке испытаний производится обкатка изделий на специальных стендах и снятие характеристик, которое проводится под контролем ОТК.

Для повышения качества производимой продукции на предприятии должна иметь место собственная СМК. В большинстве случаев высшее руководство внедряет стандарты ИСО серии 9000, преследуя одну из двух основных целей:

* использование их как средство повышения эффективности деятельности предприятия, а затем, по мере необходимости, сертификации СМК на соответствие требованиям стандартов;

* внедрение их только с целью сертификации СМК.

В АO «Шахтинский завод Гидропривод» внедрена и функционирует документированная процедура «Гарантийный ремонт продукции» на AO «Шахтинский завод Гидропривод». Разработан стандарт ГП 13-06 ОТ 03.02.2016 г., в котором описана данная процедура.

Необходимость разработки проекта стандарта «Управление несоответствующей продукцией в Ремонтном производстве» на АО «Шахтинский завод Гидропривод» обусловлена тем, что действующий на предприятии ГП 13-06 не содержит единую схему, включающую в себя все возможные варианты управления несоответствующей продукцией, а также спецификой операций технологического процесса производства продукции в цехах Ремонтного производства, которые могут служить причиной возникновения различных дефектов.

В таблице 1. приведена характеристика дефектов и причины их возникновения на примере выбранного объекта производства нерегулируемый аксиально-поршневой насосмотор МГ 80/32. 


\begin{tabular}{|c|c|c|c|c|c|c|}
\hline Impact Factor: & $\begin{array}{l}\text { ISRA (India) } \\
\text { ISI (Dubai, UAF } \\
\text { GIF (Australia) } \\
\text { JIF }\end{array}$ & $\begin{array}{l}=1.344 \\
=0.829 \\
=0.564 \\
=1.500\end{array}$ & $\begin{array}{l}\text { SIS (USA) } \\
\text { PИНЦ (Russia) } \\
\text { ESJI (KZ) } \\
\text { SJIF (Morocco) }\end{array}$ & $\begin{array}{l}=0.912 \\
=0.207 \\
=\mathbf{3 . 8 6 0} \\
=\mathbf{2 . 0 3 1}\end{array}$ & $\begin{array}{l}\text { ICV (Poland) } \\
\text { PIF (India) } \\
\text { IBI (India) }\end{array}$ & $\begin{array}{l}=6.630 \\
=1.940 \\
=4.260\end{array}$ \\
\hline
\end{tabular}

Характеристика причин спровоцировавшие изготовление бракованной продукции в 2016 году.

\begin{tabular}{|c|c|c|c|}
\hline $\begin{array}{c}\text { Вид неисправности } \\
\text { насоса-мотора. }\end{array}$ & Симптомы & Причины неисправности & $\begin{array}{c}\text { Методы устранения } \\
\text { неисправности }\end{array}$ \\
\hline 1 & 2 & 3 & 4 \\
\hline $\begin{array}{lr}\text { Обрыв } & \text { поршня } \\
\text { шатуна, задиры } & \text { и } \\
\text { риски } & \\
\text { распределителю, } & \\
\end{array}$ & $\begin{array}{l}\text { Шум при } \\
\text { нагрев, } \\
\text { вибрация. }\end{array}$ & $\begin{array}{l}\text { Усталость } \\
\text { (например, } \\
\text { пружины регулятора). }\end{array}$ & 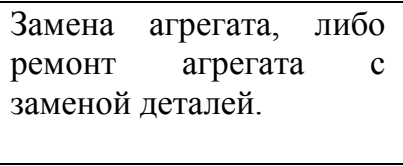 \\
\hline 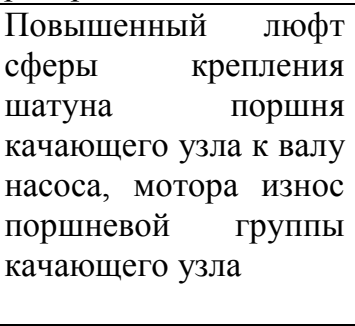 & $\begin{array}{l}\text { Шум при работе, } \\
\text { вибрация. }\end{array}$ & Естественный износ & $\begin{array}{l}\text { Соблюдение чистоты } \\
\text { рабочей жидкости, } \\
\text { температурного режима; } \\
\text { Замена агрегата, либо } \\
\text { ремонт агрегата с } \\
\text { заменой } \\
\text { соответствующих } \\
\text { деталей. }\end{array}$ \\
\hline $\begin{array}{l}\text { Механическое } \\
\text { повреждение } \\
\text { (разрушение } \\
\text { подшипников). }\end{array}$ & $\begin{array}{l}\text { Сильный шум в работе, } \\
\text { заклинивание } \\
\text { механизма. }\end{array}$ & $\begin{array}{lr}\text { Максимально } & \text { допустимая } \\
\text { нагрузка } & \text { насос-мотора, } \\
\text { неправильная } & \text { регулировка } \\
\text { клапанов } & \end{array}$ & $\begin{array}{l}\text { Своевременная } \\
\text { регулировка клапанной } \\
\text { аппаратуры; } \\
\text { Замена агрегата, либо } \\
\text { ремонт агрегата с } \\
\text { заменой } \\
\text { соответствующей } \\
\text { детали. }\end{array}$ \\
\hline $\begin{array}{l}\text { Потеря КПД, } \\
\text { неправильная } \\
\text { настройка различного } \\
\text { вида клапанов } \\
\text { (предохранительных } \\
\text { перепускных, } \\
\text { разгрузочных) } \\
\text { регулирующей } \\
\text { аппаратуры } \\
\text { (гидрораспределители, } \\
\text { блоки управления) }\end{array}$ & $\begin{array}{l}\text { Потеря } \\
\text { производительности, } \\
\text { частый выход из строя } \\
\text { уплотнений, разрыв } \\
\text { РВд, } \\
\text { повреждение } \\
\text { трубопроводов, } \\
\text { механическое } \\
\text { повреждение рабочего } \\
\text { оборудования и } \\
\text { металлоконструкций } \\
\text { строительной машины, } \\
\text { вследствие } \\
\text { избыточного усилия в } \\
\text { гидроцилиндре, } \\
\text { разрушение качающих } \\
\text { узлов гидронасоса и } \\
\text { гидромотора. }\end{array}$ & 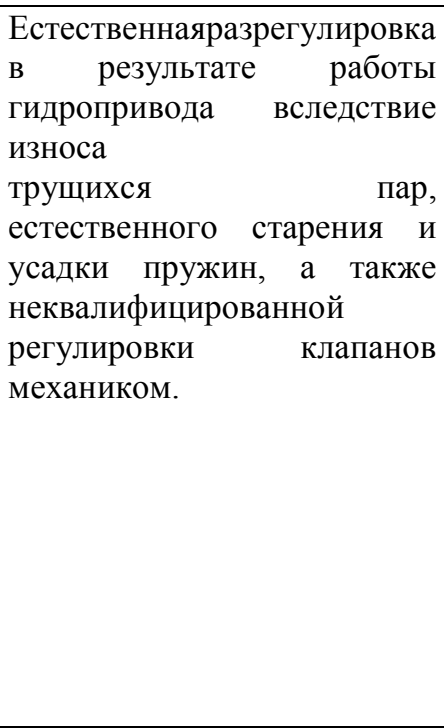 & $\begin{array}{l}\text { Квалифицированная } \\
\text { регулировка } \\
\text { гидроаппаратуры, } \\
\text { применением } \\
\text { соответствующей } \\
\text { оснастки (манометры, } \\
\text { расходомеры), замена } \\
\text { изношенных или } \\
\text { поврежденных деталей }\end{array}$ \\
\hline $\begin{array}{lr}\text { Утечка } & \text { рабочей } \\
\text { жидкости } & \text { в } \\
\text { окружающую } & \text { среду, } \\
\text { течь масла. } & \end{array}$ & & $\begin{array}{lr}\text { Повреждение } & \text { уплотнений } \\
\text { РВД, } & \text { трубопроводов } \\
\text { вследствие } & \text { естественного } \\
\text { старения } & \text { материалов и } \\
\text { механического повреждения }\end{array}$ & 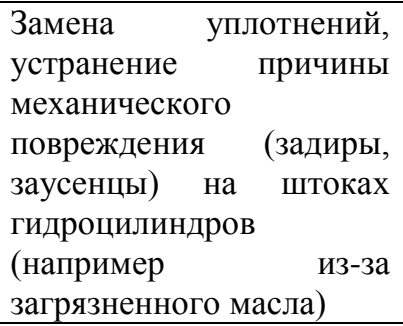 \\
\hline $\begin{array}{l}\text { Раскрытие } \\
\text { распределителя. } \\
\text { Механическое } \\
\text { повреждение } \\
\text { корпусных деталей и } \\
\text { брак изготовления } \\
\text { (пластины, корпуса). }\end{array}$ & $\begin{array}{l}\text { Ремонт или замена } \\
\text { корпусных деталей, }\end{array}$ & $\begin{array}{lr}\text { Брак при } & \text { производстве, } \\
\text { механические } & \text { внешние } \\
\text { воздействия } & \text { вследствие } \\
\text { неаккуратного обращения. }\end{array}$ & 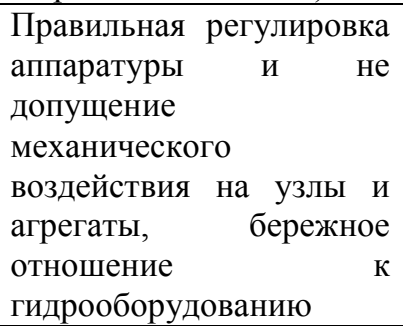 \\
\hline
\end{tabular}

ISPC Technological development, 


\begin{tabular}{|c|c|c|c|c|c|c|}
\hline Impact Factor: & $\begin{array}{l}\text { ISRA (India) } \\
\text { ISI (Dubai, UAE } \\
\text { GIF (Australia) } \\
\text { JIF }\end{array}$ & $\begin{array}{l}=1.344 \\
=0.829 \\
=0.564 \\
=1.500\end{array}$ & $\begin{array}{l}\text { SIS (USA) } \\
\text { PИНЦ (Russia } \\
\text { ESJI (KZ) } \\
\text { SJIF (Morocco }\end{array}$ & $\begin{array}{l}=\mathbf{0 . 9 1 2} \\
=\mathbf{0 . 2 0 7} \\
=\mathbf{3 . 8 6 0} \\
=\mathbf{2 . 0 3 1}\end{array}$ & $\begin{array}{l}\text { ICV (Poland) } \\
\text { PIF (India) } \\
\text { IBI (India) }\end{array}$ & $\begin{array}{l}=6.630 \\
=1.940 \\
=4.260\end{array}$ \\
\hline
\end{tabular}

\begin{tabular}{|c|c|c|c|}
\hline $\begin{array}{l}\text { Некачественная или } \\
\text { загрязненная рабочая } \\
\text { жидкость }\end{array}$ & Нагрев при работе & $\begin{array}{l}\text { Повреждение уплотнений, } \\
\text { несоблюдение чистоты в } \\
\text { процессе замены рабочей } \\
\text { жидкости. }\end{array}$ & $\begin{array}{l}\text { Слить старую жидкость } \\
\text { и заменить еe новой, } \\
\text { заливая через фильтр }\end{array}$ \\
\hline $\begin{array}{l}\text { Увеличение зазора } \\
\text { или механическое } \\
\text { повреждение } \\
\text { трущихся } \\
\text { прецизионных пар } \\
\text { (например, задиры в } \\
\text { золотниковой паре } \\
\text { гидрораспределителя, } \\
\text { зазоры в бойковой } \\
\text { паре гидромолота) }\end{array}$ & $\begin{array}{l}\text { Потеря } \\
\text { производительности }\end{array}$ & $\begin{array}{l}\text { Разрегулировка трущихся } \\
\text { пар, естественный износ } \\
\text { механизма }\end{array}$ & $\begin{array}{l}\text { Ремонт агрегатов с } \\
\text { установкой деталей для } \\
\text { получения номинального } \\
\text { зазора в трущихся парах } \\
\text { (например; золотник в } \\
\text { гидрораспределителе, } \\
\text { плунжеры в аксиально- } \\
\text { поршневомгидромоторе } \\
\text { и бойковая пара в } \\
\text { гидромолоте } \\
\text { втулка)) }\end{array}$ \\
\hline $\begin{array}{l}\text { Неправильная } \\
\text { настройка } \\
\text { гидросистемы } \\
\text { (например, настройка } \\
\text { редукционного } \\
\text { клапана на давление } \\
\text { ниже минимально } \\
\text { допустимого) }\end{array}$ & $\begin{array}{l}\text { Потеря } \\
\text { производительности, } \\
\text { вибрация при работе на } \\
\text { низких оборотах. }\end{array}$ & $\begin{array}{l}\text { Неправильная } \quad \text { настройка } \\
\text { клапанной аппаратуры }\end{array}$ & $\begin{array}{l}\text { Квалифицированная } \\
\text { настройка } \\
\text { аппаратуры }\end{array}$ \\
\hline
\end{tabular}

Документированная политика и цели предприятия по повышению качества продукции в рамках СМК приведена в таблице 2.

Таблища 2

Политика и цели предприятия по повышению качества продукции в рамках СМК

\begin{tabular}{|c|c|c|c|}
\hline Номер & $\begin{array}{c}\text { Наименование } \\
\text { документа }\end{array}$ & & Владелец \\
\hline ГП 13-03 & $\begin{array}{l}\text { Внутренний аудит } \\
\text { менеджмента качества }\end{array}$ & Процедура & $\begin{array}{l}\text { Зам. исполнительного директора } \\
\text { по качеству }\end{array}$ \\
\hline ГП 13-06 & Гарантийный ремонт продукции & Процесс & $\begin{array}{l}\text { Зам. исполнительного директора } \\
\text { по качеству }\end{array}$ \\
\hline ГП 13-05 & $\begin{array}{l}\text { Управление документацией } \\
\text { записями }\end{array}$ & Процедура & $\begin{array}{l}\text { Зам. исполнительного директора } \\
\text { по качеству }\end{array}$ \\
\hline ГП 13-01 & $\begin{array}{c}\text { Управление } \\
\text { продукцией }\end{array}$ & Процедура & $\begin{array}{l}\text { Зам. исполнительного директора } \\
\text { по качеству }\end{array}$ \\
\hline ГП 13-02 & Организация контроля качества & Процедура & $\begin{array}{l}\text { Зам. исполнительного директора } \\
\text { по качеству }\end{array}$ \\
\hline ГП 11-01 & Закупки & Процедура & Коммерческий директор \\
\hline ГП 08-01 & $\begin{array}{l}\text { Проектирование, } \frac{2}{2} \text { разработка } \\
\text { продукции и постановка на } \\
\text { серийное производство }\end{array}$ & Процесс & Начальник КТО \\
\hline ГП 20-01 & Производство продукции & Процедура & Начальник производства \\
\hline ГП 13-04 & Удовлетворенность потребителей & Процедура & $\begin{array}{l}\text { Зам. исполнительного директора } \\
\text { по качеству }\end{array}$ \\
\hline ГП 06-01 & $\begin{array}{l}\text { Технологическая } \\
\text { производства }\end{array}$ & Процедура & Начальник КТО \\
\hline ГР 13-02 & $\begin{array}{ccc}\text { Организация } & \text { и } & \text { порядок } \\
\text { проведения «Дней качества» }\end{array}$ & $\begin{array}{l}\text { Руководящи } \\
\text { й документ }\end{array}$ & $\begin{array}{l}\text { Зам. исполнительного директора } \\
\text { по качеству }\end{array}$ \\
\hline ГМ 13-01 & $\begin{array}{ll}\text { Статистические } & \text { методы } \\
\text { управления качеством } & \\
\end{array}$ & Методика & $\begin{array}{l}\text { Зам. исполнительного директора } \\
\text { по качеству }\end{array}$ \\
\hline
\end{tabular}


Предприятие имеет собственную базу, состоящую из нормативной документации, регулирующей деятельность и производство, характеристика которой приведена ниже:

1. РК 01-2012. Руководство по качеству. Руководство по качеству является основополагающим документом системы менеджмента качества (СМК) ОАО «Шахтинский завод Гидропривод», который разработан в соответствии с требованиями международного стандарта ГОСТ Р ИСО 9001-2015.

Руководство по качеству описывает структуру и содержание системы менеджмента качества, направленную на обеспечение соответствия продукции требованиям потребителя и обязательным требованиям нормативной документации (НД), а также излагает Процедуры (или дает ссылки на них), разработанные в рамках СМК, описывает взаимодействие между процессами системы менеджмента качества.

2. ГП 13-03. Внутренний аудит системы менеджмента качества.

Настоящая процедура является обязательной документированной процедурой, которая устанавливает порядок и последовательность действий при проведении внутренних аудитов (проверок) системы менеджмента качества.

Внутренние аудиты СМК на предприятии проводятся с целью:

^проверки соответствия СМК АО «ШЗГ» требованиям ГОСТ Р ИСО 9001-2015;

夫оценки соответствия СМК требованиям, установленным внутренней документацией АО «ШЗГॅ;

夫оценки способности СМК к результативному и эффективному функционированию;

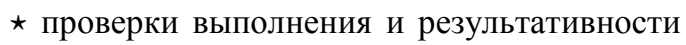
корректирующих и предупреждающих действий по несоответствиям, выявленным при проведении предыдущих аудитов (в т.ч. внешних);

夫определения областей деятельности для улучшения, возможности и путей совершенствования СМК.

Настоящая процедура предназначена для использования при планировании, проведении внутренних аудитов на АО «ШЗГ» и служит руководством для работников, осуществляющих внутренние аудиты, для структурных подразделений.

3. ГП 13-05. Управление документацией и записями.

4. ГП 13-01. Управление несоответствующей продукцией. Настоящий документ является обязательной документированной процедурой, которая устанавливает:

a) конкретные обязанности структурных подразделений, должностных лиц и отдельных исполнителей

по

управлению

несоответствующей продукцией;

б) цели, задачи, сроки, порядок оформления и регистрации записей и документов по управлению несоответствующей продукцией в основном и вспомогательном производстве;

в) требования по идентификации и утилизации несоответствующей продукции.

1.2. Применяется при управлении несоответствующей продукцией, еe идентификации; при принятии необходимых мер по исключению появления потенциальных несоответствий, разработке и внедрении корректирующих и предупреждающих действий, связанных с изготовлением, реализацией, послепродажным обслуживанием на всех этапах; при анализе качества.

1.3. Настоящий документ распространяется на все структурные подразделения АО «ШЗГ», чья деятельность связана с выпуском продукции основного производства.

5. ГП 13-02. Организация контроля качества.

Настоящий документ устанавливает порядок организацию контроля качества продукции на предприятии БТК СК и конкретные обязанности должностных лиц и отдельных исполнителей по контролю качества продукции всего предприятия; управлению и идентификации несоответствующей продукции и обязателен для всех служб и всех работников БТК, и при контроле качества продукции, управлении несоответствующей продукцией и еe идентификации.

6. ГП 11-01. Закупки.

Настоящая процедура устанавливает порядок работы в области оценки и выбора поставщиков, ведения анкеты по поставщикам и определения категории надежности поставщика, определяет единый порядок проведения закупок комплектующих изделий, материалов и полуфабрикатов, их складирования, обеспечения производства и гарантийного обслуживания продукции.

6.1 Положения документированной процедуры распространяются на все виды деятельности коммерческо-сбытового отдела, касающиеся планирования закупок, поиска, оценки и отбора потенциальных поставщиков, согласования с ними условий договоров, заключения договоров и контроля их исполнения.

6.2 Целью процедуры является своевременное обеспечение предприятия всеми необходимыми для его производственной деятельности материальными ресурсами требуемого качества, влияющими на последующие стадии выпуска готовой продукции в установленные сроки и в необходимом объеме.

6.3 Настоящий стандарт предназначен для работников коммерческо-сбытового отдела. 
7. ГП 20-01. Производство продукции.

Настоящий документ устанавливает порядок выполнения процесса «Производство продукции» (далее «процесса») и предназначен для регламентации и управления деятельностью подразделений по производству продукции.

Целью процесса является:

* изготовление продукции в соответствии с КД и ТД на основании и в сроки, утвержденные планом производства;

* удовлетворение потребностей потребителя продукции в области качества;

*постоянное улучшение системы менеджмента качества и результатов процесса;

* обеспечение предприятия необходимыми для жизнедеятельности ресурсами;

* обеспечение нормальных условий труда и роста производительности.

Настоящий процесс «Производство продукции» регламентирует действия и взаимосвязи руководителей и специалистов предприятия, направленные на обеспечение производства основными, вспомогательными материалами, ресурсами, необходимой документацией для качественного выполнения поставленной цели, и подлежит применению во всех службах и подразделениях предприятия.

8. ГП 13-04. Удовлетворенность потребителей.

Настоящая процедура устанавливает порядок определения уровня удовлетворенности потребителей.

Настоящий стандарт предназначен для работников, которые определяют уровень удовлетворенности потребителей.

9. ГР 13-02. Организация и порядок проведения «Дней качества».

Настоящий документ устанавливает порядок организации и проведения совещаний «Дней качества» на ОАО «ШЗГ», в производственных подразделениях и отделах.

Настоящий документ распространяется на все службы и подразделения предприятия.

10. ГМ 13-01. Статистические методы управления качеством.

Настоящая документированная информация является обязательной документированной методикой, которая устанавливает порядок статистического контроля качества продукции в AO «ШЗГ» .

10.1 Статистический контроль качества продукции является элементом механизма управления качеством продукции и регулирования взаимоотношений между поставщиком и потребителем, при этом проверка группы или партии изделий осуществляется до и после процесса, а не по ходу процесса.

10.2 Главная цель применения статистических методов - регулирование процесса создания изделия высокого качества на всех стадиях от маркетинга до технического обслуживания с меньшими экономическими затратами и высокой эффективностью.

10.3 Статистические методы предусматривают сбор, систематизацию и математическую обработку результатов производственной деятельности, анализ информации для принятия корректирующих и предупреждающих мер, дальнейшее исследование объекта контроля для достижения приемлемого (оптимального) уровня качества.

10.4 Статистические методы позволяют вести:

^ работы по повышению долговечности, надежности;

* постоянное регулирование производственного процесса, своевременное выявление и устранение причин дефектов;

^ регулярные работы по управлению сбытом, прогнозированию спроса и принятию обоснованных решений при изучении рынка сбыта;

^ прогнозирование требований к качеству перспективных моделей продукции, их модификаций в зависимости от спроса;

^ работы по ценообразованию продукции;

^ учетную, справочную информацию о сырье, материалах, комплектующих; анализ поставщиков; учет, информацию и анализ всех видов контроля качества продукции;

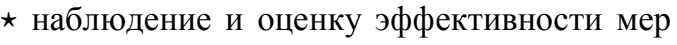
по предупреждению дефектов;

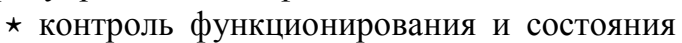
системы качества;

^ контроль в области обучения и подготовки кадров по мере развития системы менеджмента качества (СМК);

10.5 При осуществлении статистического контроля качества продукции могут быть использованы следующие методы:

* гистограммы;

* диаграмма Парето (по результатам деятельности и причинам);

* диаграмма Исикавы (причин и результатов);

* диаграмма расслоения (разброса);

* контрольные листки.

10.6 Структура оценки качества на базе статистических методов контроля в подразделениях и отделах а именно:

a) экспертная оценка объектов контроля;

б) сбор статистических данных;

в) систематизация данных;

г) анализ статистических данных, поиск причин несоответствия, использование статистических методов;

д) принятие мер корректирующих и предупреждающих действий; 
е) проведение мероприятий и исследований;

ж) контроль исполнения;

и) создание новых видов продукции.

11. ГП 13-06. Настоящий документ описывает процесс «Гарантийный ремонт продукции» и устанавливает порядок работы с претензиями потребителей. Стандарт предназначен для владельца процесса и работников, которые занимаются претензиями потребителей[24].

12. ГП 06-01. Настоящий документ устанавливает порядок выполнения процесса «Технологическая подготовка производства» и предназначен для:

a) для регламентации и управления деятельностью подразделения по технологической подготовке производства новых видов продукции.

б) постоянного улучшения системы менеджмента качества и результатов процесса.

Требования процесса распространяются на все функции и работы, выполняемые в ходе процесса в технологическом бюро КТО, а также при взаимодействии с соисполнителями.

13. ГП 08-01. Настоящий документ устанавливает порядок выполнения процесса «Проектирование, разработка продукции и постановка на производство» и предназначен для:

a) регламентации и управления деятельностью подразделения по проектированию и разработке новых видов продукции;

б) постоянного улучшения системы менеджмента качества и результатов процесса.

Требования процесса распространяются на все функции и работы, выполняемые в ходе процесса в конструкторской группе КБ КТО, а также при взаимодействии с соисполнителями.

Не исполнение документированной процедуры в области политики и целипредприятия приведёт к производству дефектной продукции.

Рассмотрим некоторые нарушения:

^утечка рабочей жидкости в окружающую среду, течь масла;

^неправильная настройка гидросистемы (например,

^настройка редукционного клапана на давление ниже минимально допустимого);

^механическое повреждение (разрушение подшипников);

^потеря КПД, неправильная настройка различного вида клапанов (предохранительных перепускных, разгрузочных) и регулирующей аппаратуры (гидрораспределители, блоки управления);
^ раскрытие распределителя; механическое повреждение корпусных деталей и брак изготовления (пластины, корпуса).

Данный перечень дефектов связан с нарушением норм ГП 20-01«Производство продукции», так как Продукция не изготавливалась в соответствии с конструкторской документацией. Ответственный - начальник производства. Для решения данной проблемы необходимо строгое соблюдение правил на производстве в соответствии с конструкторской документацией; а обрыв поршня шатуна, задиры и риски по распределителю, задир на оборванном шатуне; увеличение зазора или механическое повреждение трущихся прецизионных пар (например, задиры в золотниковой паре гидрораспределителя, зазоры в бойковой паре гидромолота); повышенный люфт сферы крепления шатуна поршня качающего узла к валу насоса, мотора износ поршневой группы качающего узла. Данный перечень дефектов связан с нарушением норм процесса ГП 08-01 «Проектирование, разработка продукции и постановка на серийное производство». Наблюдались нарушения при проектировании продукции/создании чертежей деталей и сборочных единиц, нанесение неправильных размеров и допусков. Ответственный: начальник конструкторского бюро. Меры по устранению: повышение квалификации персонала, более тщательная проверка разработанной КД отделом нормоконтроля.

За нормоконтроль в отвечает процедура ГП 13-02 «Организация контроля качества». В случае несоблюдения работы этой процедуры на производстве допускается несоответствующая должным требованиям конструкторская документация.

Процесс ГП 08-01 «Проектирование, разработка продукции и постановка на серийное производство» и процедура ГП 20-01 «Производство продукции» для достижения наибольшей эффективности производства и сведения к минимуму количества бракованной продукции, выпускаемой предприятием, нуждаются в строгом соблюдении и доработке.

Описание процесса ГП 08-01:

Ответственный исполнитель - начальник КБ КТО предприятия.

Функции, права и ответственность владельцев процесса установлены в ГР 01-01 «Порядок назначения, функции, права и ответственность владельцев процесса».

Входы процесса:

Входы процесса ГП 08-01

Таблица 3 


\begin{tabular}{|l|ll|}
\hline Поставщик & Вход & \\
\hline Маркетинговый отдел ТД & 1. & Предложения о востребованных изделиях \\
& 2. & Технические данные аналогов \\
\hline Техсовет & 1. & План новой техники на год \\
\hline
\end{tabular}

Выходы процесса:

Выходы процесса ГП 08-01

\begin{tabular}{|l|ll|}
\hline Потребители & \multicolumn{2}{|l|}{ Выход } \\
\hline ОКЛ и ИЛ & 1. & Конструкторская документация с присвоенным литером «О», «О1» \\
& 2. & $\begin{array}{l}\text { Опытный образец изделия } \\
\text { Акт о результатах приемки опытного образца } \\
\end{array}$ \\
\hline П. & Протокол испытаний опытного образца \\
\hline Производство & 1. & Комплект конструкторской документации с присвоенной литерой \\
& «А» & Готовое изделие \\
\hline
\end{tabular}

Для реализации процедуры ГР 01-01 и соблюдения процесса ГП 08-01 сотрудники КБ КТО используют высокоэффективное программное обеспечение «Компас 3D» и «Лоцман», что обеспечивает им результативность их деятельности, а именно:

夫 сроки разработки КД (согласно с планом новой техники на год);

* соответствие КД требованиям НД;

* соответствие опытного образца требованиям ТЗ и КД;

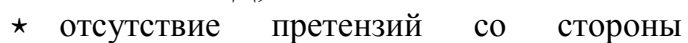
потребителей к КД и опытному образцу (акт приемочной комиссии);

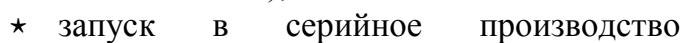
установочной серии (согласно с планом новой техники на год).

Согласно процессу, для конструирования деталей, сборочных единиц и изделий используются такие системы автоматизированного проектирования как «КОМПАС» и «ЛОЦМАН». Для проектирования сложных сборочных единиц данного программного обеспечения недостаточно. Для наиболее эффективного проектирования предлагается использовать САПР NX (Unigraphics). Данная САПР обладает самой высокой производительностью и расширенным функционалом проектирования. Большим недостатком является стоимость данной САПР. На рынке систем автоматизированного проектирования NX имеет самую большую стоимость за одну единицу лицензии данного программного продукта.

Эффективность проектирования и разработки продукции зависит не только от используемого оборудования и программного обеспечения, но и от квалификации и профессионализма служащего в конструкторском бюро персонала.

Описание процедуры ГП 20-01 «Производство продукции»:

Ответственный исполнитель - начальник производства.

Функции, права и ответственность владельцев процесса установлены в ГР 01-01 «Порядок назначения, функции, права и ответственность владельцев процесса».

Входы процесса: план производства, сырье, комплектующие, материалы, литье, полуфабрикаты, тех. ресурсы.

Выходы процесса: готовая деталь, узел, изделие.

Необходимо внедрить информацию о способе сведения к минимуму браков на производстве.

Первый шаг. Составить таблицу с характеристикой всех случаев брака на предприятии. Для показательной статистики рекомендуется анализ данных минимум за год.

Второй шаг. Объединить аналогичные причины производственного брака в общую группу. Благодаря выделению группы схожих причин брака удастся рассчитать число случаев за период, также потери от них и пути их устранения.

Третий шаг. Проведение анализа. Обычно после группировки оказывается, что только несколько одинаковых причин регулярно повторяются, приводя к основной доле производственного брака. Именно они заслуживают первоочередного внимания.

Четвертый шаг - установить причину брака на предприятии с максимальным количеством случаев и наибольшими потерями. 


\begin{tabular}{|c|c|c|c|c|c|c|}
\hline Impact Factor: & $\begin{array}{l}\text { ISRA (India) } \\
\text { ISI (Dubai, UAE } \\
\text { GIF (Australia) } \\
\text { JIF }\end{array}$ & $\begin{array}{l}=1.344 \\
=0.829 \\
=0.564 \\
=1.500\end{array}$ & $\begin{array}{l}\text { SIS (USA) } \\
\text { PИНЦ (Russia) } \\
\text { ESJI (KZ) } \\
\text { SJIF (Morocco) }\end{array}$ & $\begin{array}{l}=0.912 \\
=\mathbf{0 . 2 0 7} \\
=\mathbf{3 . 8 6 0} \\
=\mathbf{2 . 0 3 1}\end{array}$ & $\begin{array}{l}\text { ICV (Poland) } \\
\text { PIF (India) } \\
\text { IBI (India) }\end{array}$ & $\begin{array}{l}=6.630 \\
=1.940 \\
=4.260\end{array}$ \\
\hline
\end{tabular}

Пятый шаг - снижать или исключать вероятность повторения частых причин производственного брака. В бережливом производстве существует термин пока-ёкэ (pokayoke, япон. - защита от ошибок). Данный термин предполагает: чтобы предотвратить производственный брак в будущем, требуется обеспечение таких условий, когда физически невозможно повторение брака, чтобы не было у сотрудника возможности повторной ошибки и пр. До решения проблемы наше руководство нередко обвиняло подчиненных, ссылаясь на проблему человеческого фактора. Однако совершенствование производственного процесса позволило кардинально уменьшить вероятность ошибки на предприятии - меньше начали выполняться операции в уме, ответственность была делегирована между разными сотрудниками, удалось улучшить благоприятные условия для работы. Бережливое производство: система и примеры

Шестой шаг - разработка и введение в работу системы мотивации персонала, ориентированной на сокращение производственного брака. В числе возможных мер можно отметить определенный размер депремирования сотрудника за выпуск каждой тонны товаров с браком, либо при допущенных ошибках. Также могут выплачиваться премии за уменьшение доли брака до установленного норматива, индивидуальные показатели работников можно размещать на стендах - будет стимулировать желание работников сократить уровень брака.

Седьмой шаг - организация постоянного процесса повышения качества. Для каждого сотрудника нужно определить индивидуальные показатели качества. Как правило, достаточно 1-3 показателей, в рамках партисипативного управления.

Для решения всевозможных проблемы, связанных с появлением брака, неполадками оборудования, увеличением времени от выпуска партии изделий до её сбыта, наличием на складе нереализованной продукции, поступлением рекламаций применяется диаграмма Парето.

Диаграмма Парето позволяет распределить усилия для разрешения возникающих проблем и установить основные факторы, с которых нужно начинать действовать $\mathrm{c}$ целью преодоления возникающих проблем.

В таблицах 5 и 6 представлены перечень дефектов для построения диаграмм Парето за 2016 и 2017(ожидаемый) год соответственно

\section{Характеристика дефектов на АО «ШЗГ» за 2016 год}

Таблица 5

\begin{tabular}{|l|l|l|l|}
\hline \multicolumn{1}{|c|}{ Дефект } & $\begin{array}{c}\text { Число } \\
\text { обнаруженных } \\
\text { дефектов }\end{array}$ & Накопленная доля обнаружений & $\begin{array}{c}\text { Суммарное } \\
\text { число } \\
\text { дефектов, } \\
\%\end{array}$ \\
\hline Брак шайбы & 78 & $16,5 \%$ & $16 \%$ \\
\hline Брак блока & 74 & $15,6 \%$ & $32 \%$ \\
\hline Брак корпуса & 70 & $14,8 \%$ & $47 \%$ \\
\hline Обломан палец & 64 & $13,5 \%$ & $60 \%$ \\
\hline Разрушение поршневого кольца & 57 & $12,1 \%$ & $73 \%$ \\
\hline Раскрылся распределитель & 54 & $11,4 \%$ & $84 \%$ \\
\hline Обрыв поршня шатуна & 32 & $6,8 \%$ & $91 \%$ \\
\hline Задиры на распределителе & 30 & $6,3 \%$ & $97 \%$ \\
\hline Прочие дефекты & 14 & $3,0 \%$ & $100 \%$ \\
\hline Итого & 473 & & \\
\hline
\end{tabular}




\begin{tabular}{|c|c|c|c|c|c|c|}
\hline Impact Factor: & $\begin{array}{l}\text { ISRA (India) } \\
\text { ISI (Dubai, UAF } \\
\text { GIF (Australia) } \\
\text { JIF }\end{array}$ & $\begin{array}{l}=1.344 \\
=0.829 \\
=0.564 \\
=1.500\end{array}$ & $\begin{array}{l}\text { SIS (USA) } \\
\text { PИНЦ (Russia) } \\
\text { ESJI (KZ) } \\
\text { SJIF (Morocco) }\end{array}$ & $\begin{array}{l}=0.912 \\
=0.207 \\
=\mathbf{3 . 8 6 0} \\
=\mathbf{2 . 0 3 1}\end{array}$ & $\begin{array}{l}\text { ICV (Poland) } \\
\text { PIF (India) } \\
\text { IBI (India) }\end{array}$ & $\begin{array}{l}=6.630 \\
=1.940 \\
=4.260\end{array}$ \\
\hline
\end{tabular}

Таблица 6

Характеристика дефектов на АО «ШЗГ» за 2017 год(ожидаемый)

\begin{tabular}{|l|l|l|l|}
\hline \multicolumn{1}{|c|}{ Дефект } & $\begin{array}{c}\text { Число } \\
\text { обнаружений }\end{array}$ & \multicolumn{1}{c|}{$\begin{array}{c}\text { Накопленная доля } \\
\text { обнаружений }\end{array}$} & \multicolumn{1}{c|}{ Суммарно } \\
\hline Задиры на распределителе & 24 & $12,4 \%$ & $12 \%$ \\
\hline Брак шайбы & 24 & $12,4 \%$ & $25 \%$ \\
\hline Обрыв поршня шатуна & 23 & $11,9 \%$ & $37 \%$ \\
\hline Раскрылся распределитель & 22 & $11,3 \%$ & $48 \%$ \\
\hline Брак корпуса & 22 & $11,3 \%$ & $59 \%$ \\
\hline Брак блока & 22 & $11,3 \%$ & $71 \%$ \\
\hline Обломан палец & 20 & $10,3 \%$ & $81 \%$ \\
\hline Разрушение поршневого кольца & 19 & $9,8 \%$ & $91 \%$ \\
\hline Прочие дефекты & 18 & $9,3 \%$ & $100 \%$ \\
\hline Итого & 194 & & \\
\hline
\end{tabular}

На рисунках 1 и 2 приведены результаты исследований. характеризующие дефекты в виде

диаграммы Парето соответственно за 2016 и 2017

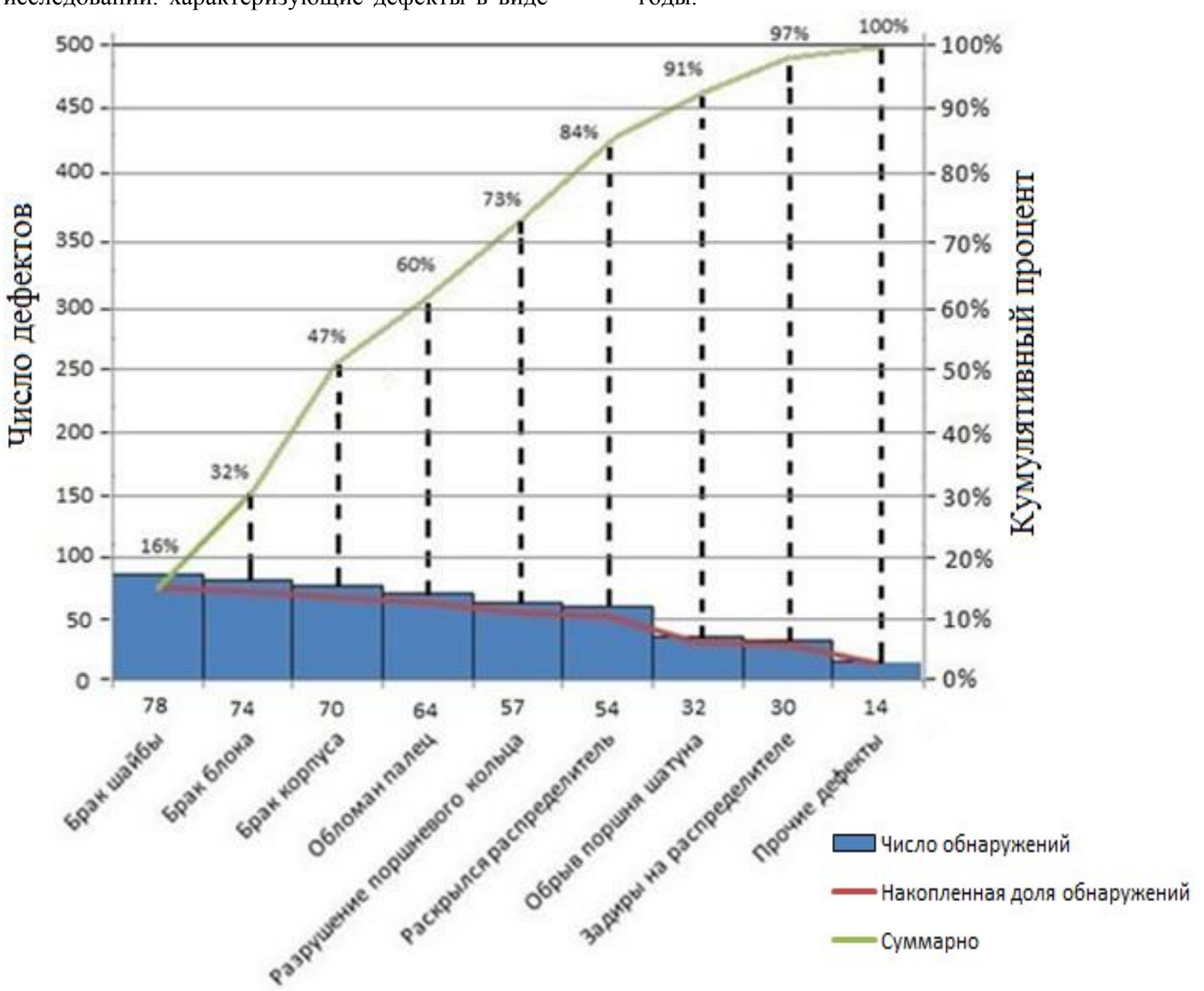

Рисунок 1 - Диаграмма Парето по дефектам продукции, производимой АО «Шахтинский завод Гидропривод» за 2016 год 


\begin{tabular}{l|lrl|l|ll} 
& ISRA (India) & $=\mathbf{1 . 3 4 4}$ & SIS (USA) & $=\mathbf{0 . 9 1 2}$ & ICV (Poland) & $=\mathbf{6 . 6 3 0}$ \\
Impact Factor: & ISI (Dubai, UAE) $=\mathbf{0 . 8 2 9}$ & PUHU (Russia) $=\mathbf{0 . 2 0 7}$ & PIF (India) & $=\mathbf{1 . 9 4 0}$ \\
& GIF (Australia) & $\mathbf{0 . 5 6 4}$ & ESJI (KZ) & $=\mathbf{3 . 8 6 0}$ & IBI (India) & $\mathbf{4 . 2 6 0}$
\end{tabular}

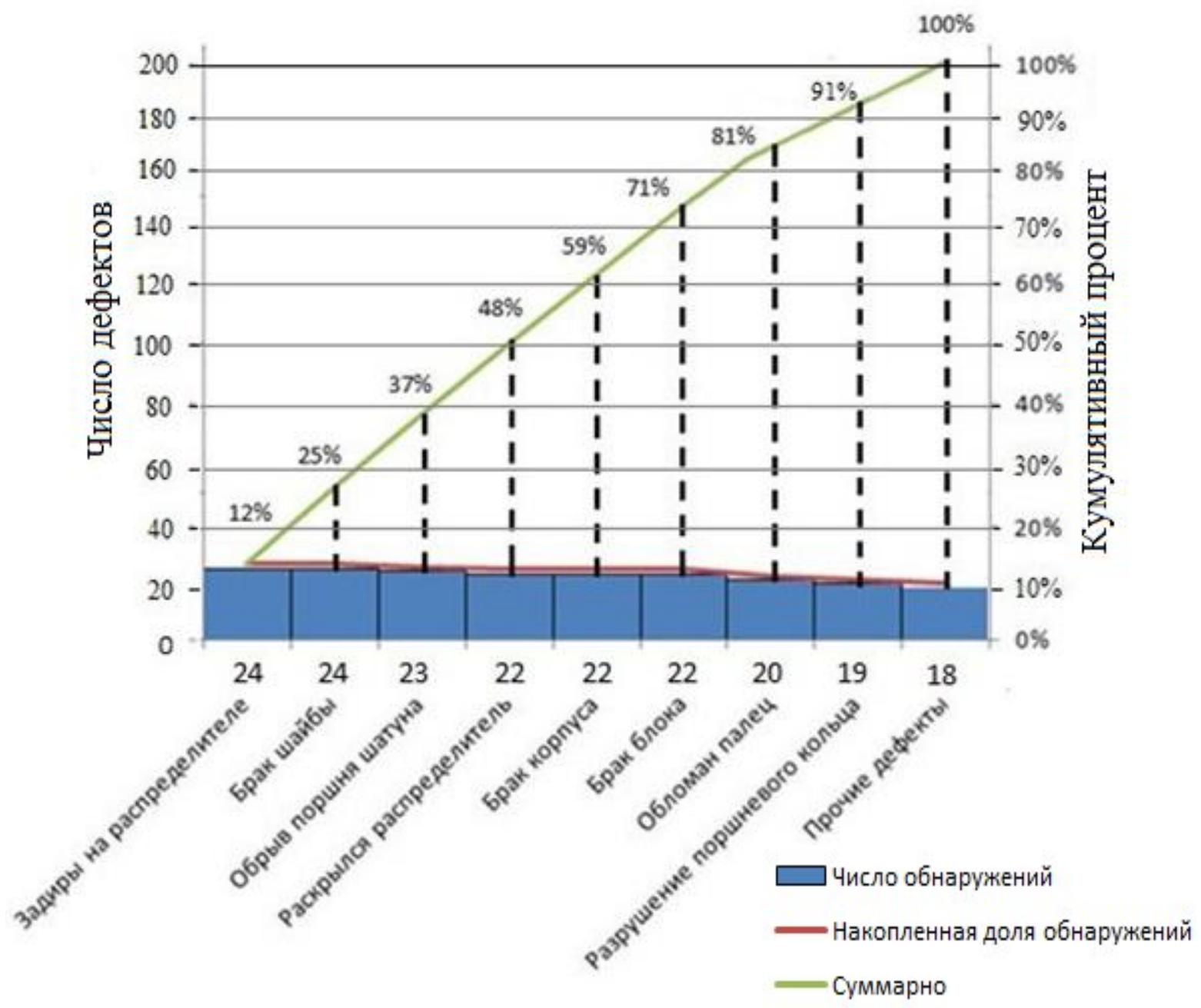

Рисунок 2 - Диаграмма Парето по дефектам продукции, производимой АО «Шахтинский завод Гидропривод» за 2017 год

За 2017 год количество дефектной продукции сократиться, но при этом с сожалением наиболее часто встречаемые дефектами остались по-прежнему брак корпуса и шайбы, а также задиры на распределителе, обрыв поршня шатуна и проблема с раскрытием распределителя, но в процентном отношение произошло их существенное сужение. Рисунок 2.

Как видно, в ожидаемом 2017 год в результате реализации процедур в рамках СМК и партисипатичного управления предприятием существенно снизилась текучесть кадров и повысилась их квалификация.

Рассмотрим были ли наши усилия в рамках СМК партисипатичного управления эффективными, чтобы создать на производстве политику качества с таким акцентом чтобы гарантировать потребителю бездефектную продукцию.

Обеспечение качества продукции связано с затратами. Качество продукции должно гарантировать потребителю удовлетворение его запросов, ее надежность и экономию затрат. Эти свойства формируются в процессе всей воспроизводственной деятельности предприятия, на всех ее этапах и во всех звеньях. Вместе с ними образуется стоимостная величина продукта, характеризующая эти свойства от планирования разработок продукции до ее реализации и послепродажного обслуживания.

Рекламация - претензия, предъявляемые покупателем к продавцу в связи с несоответствием качества или количества поставляемого товара условиям договора. Рекламации могут предъявляться только по таким вопросам, которые не являлись предметом приемки товара, произведенной в соответствии с условиями договора.

Политика предприятия должна изначально иметь целью высокое качество продукции. Однако брак, являющийся его противоположностью, может возникнуть на любом предприятии. Его необходимо учитывать. Брак может быть обнаружен на самом

ISPC Technological development, 
предприятии - производителе продукции и за егопределами.

Проявившийся в сфере реализации или в процессе использования продукции брак свидетельствует как о плохом качестве продукции, так и о качестве работы предприятия.

Продукция АО «ШЗГ» состоит из 11 разновидностей насос-моторов, с разной ценовой категорией. Потребителю было отгружено в 2016 году, 46300 штук насос-моторов. Количество дефектной продукции составило 473 штуки. Определим экономический эффект полученный предприятием за 2016 год.

Годовой объем реализации АО «ШЗГ» за 2016 год составил:

$\mathrm{O}_{\mathrm{n}}=(4300 \cdot 11600)+(4200 \cdot 12200)+(4400 \cdot 20000)+$ $+(5000 \cdot 12420)+(3600 \cdot 38500)+(3548 \cdot 35900)+$ $+(4365 \cdot 130900)+(4502 \cdot 25000)+(638 \cdot 48600)+$ $+(4690 \cdot 59900)+(39800 \cdot 7057)=1541148100$ рублей

С учетом возврата продукции из-за брака, потери составят :

$\Pi=(40 \cdot 11600)+(46 \cdot 12200)+(50 \cdot 20000)+$

$+(36 \cdot 12420)+(42 \cdot 38500)+(70 \cdot 35900)+(19 \cdot 130900)+$ $+(11 \cdot 25000)+(22 \cdot 48600)+(14 \cdot 59900)+(123 \cdot 39800)=$ $=16167620$ рублей

Определим процент потерь за счет дефектной продукции 2016 года, которая составила 473 изделия:

$$
\mathrm{a}_{\text {дф }}=\frac{16167620}{1541148100} \cdot 100 \%=1,05 \%
$$

Определим средневзвешенную массу одного насоса:

$$
\mathrm{C}_{\text {p.ap. } \mathrm{B}}=\frac{(7+12+15+20+30+50+48+70+80+27+58)}{11}=38 \mathrm{\kappa \Gamma}
$$

Учитывая, что бракованные изделия не подлежат восстановлению и ремонту, то на предприятии их утилизируют, а полученный металл используют для производства новых изделий. Общая масса металла, полученная за счет утилизации товара, равна :

$\mathrm{m}=473 \cdot 38=17974$ кг

Затраты на утилизацию будут складываться из затрат на электроэнергию (23 руб.на 1 кг), из зарплаты рабочим (13 руб. на 1 кг) , и амортизационных отчислений за счет использования оборудования ( 76 руб. на 1 кг), что составит 2013088 рублей.

$\mathrm{C}=(76+13+23) \cdot 17974=2013088$ рублей

С учетом договорных цен на металл, после переплавки мы получим: (договорная стоимость 1 кг металла-350 рублей), что составило 6290900 рублей.

$$
\mathrm{P}=17974 \cdot 350=6290900 \text { рублей }
$$

Возврат денег предприятию в 2016 году за счет утилизации с учетом затрат на неё:

$Э_{\text {уб }}=6290900-2013088=4277812$ рублей

Теперь определим итоговый годовой объем реализации с вычетом на потери от бракованной продукции:

$$
\mathrm{O}_{\mathrm{P}}=15541148100-16167620+4277812=
$$
1542258292 рублей

По данным предприятия о реализации продукции АО «ШЗГ», за 10 месяцев 2017 года объем реализации составил 38584 штук, а объем дефектной продукции составит 160 штук, следовательно, с учетом объёма реализации продукции за 2017 год а именно- 46300 штук. Количество ожидаемой дефектной продукции составит всего 194 штуки.

Планируемый годовой объем реализации АО «ШЗГ» за 2017 год составит:

$\mathrm{O}_{\mathrm{P}}=4300 \cdot 11700+4200 \cdot 12300+4400 \cdot 20100+$ $+5000 \cdot 12520+3600 \cdot 38600+3548 \cdot 35900+$ $+4365 \cdot 130900+4502 \cdot 25100+638 \cdot 48700+$ $+4690 \cdot 59900+39900 \cdot 7057=1740252100$ рублей

С учетом возврата продукции из-за брака, потери составят :

$\Pi=18 \cdot 11700+19 \cdot 12300+17 \cdot 20100+18 \cdot 12520+$ $+19 \cdot 38600+18 \cdot 35900+16 \cdot 130900+19 \cdot 25100+$ $+18 \cdot 48700+17 \cdot 59900+39900 \cdot 15=7455660$ рублей

Определим процент потерь от объема реализации в 2017 году

$$
\mathrm{a}_{\text {дф }}=\frac{7455660}{1740252100} \cdot 100 \%=0,42 \%
$$

Учитывая, что бракованные изделия не подлежат восстановлению и ремонту, то на предприятии их утилизируют, а полученный металл используют для производства новых изделий . Общая масса металла, полученная за счет утилизации товара ровна :

$\mathrm{m}=194 \cdot 38=7312$ кг

Затраты на утилизацию будут складываться из электроэнергии( 25 руб.на 1 кг), зарплаты рабочего(15 руб. на 1 кг), и амортизационных отчислений за счет использования оборудования ( 80 руб. на 1 кг).

$$
\mathrm{C}=(80+15+25) \cdot 7312=87740 \text { рублей }
$$

С учетом договорных цен на металл, после переплавки мы получим: (договорная стоимость 1 кг металла-360 рублей)

$$
\mathrm{P}=7312 \cdot 360=263230 \text { рублей }
$$




\begin{tabular}{l|lrl|l|ll} 
& ISRA (India) & $=\mathbf{1 . 3 4 4}$ & SIS (USA) & $=\mathbf{0 . 9 1 2}$ & ICV (Poland) & $=\mathbf{6 . 6 3 0}$ \\
Impact Factor: & ISI (Dubai, UAE) $=\mathbf{0 . 8 2 9}$ & PUHL (Russia) $=\mathbf{0 . 2 0 7}$ & PIF (India) & $=\mathbf{1 . 9 4 0}$ \\
& GIF (Australia) & $\mathbf{0 . 5 6 4}$ & ESJI (KZ) & $=3.860$ & IBI (India) & $=\mathbf{4 . 2 6 0}$ \\
& JIF & $\mathbf{1 . 5 0 0}$ & SJIF (Morocco) & $=\mathbf{2 . 0 3 1}$ & & \\
\hline
\end{tabular}

Возврат денег предприятию в 2017 году за счет в результате утилизации с учетом затрат на неё:

$Э_{\text {уб }}=263230-877440=1754880$ рублей

Определим годовой объем реализации с вычетом потерь :

$\mathrm{O}_{\mathrm{P}}$ $=1740252100$ -

$7455660+1754880=1731041560$ рублей

Уменьшение потерь с 2016 по 2017 в процентном соотношении составит :

$\Pi_{\mathrm{y}}=1,05-0,42=1,008 \%$
Эффект от реализации мероприятий по устранению дефектов за счет совершенствования нормативной документации АО «ШЗГ» составит 188783268 рублей.

Э=1731041560-1542258292=188783268 рублей

\section{Conclusion}

Полученные результаты подтверждают правильность выбранного решения о внедрении СМК и партисипатичного управления производством и предполагает их неукоснительное исполнение в бедующем.

\section{References:}

1. (2014) GOST replacement of P 52543-2006. Hydraulic actuators are three-dimensional. Safety roller requirements. Enter. 2007.01.01. M.: Standartinform, 2014. 27 p.

2. (2014) TR maximum TC 010/2011. The technical regulations of the Customs also have a union. On the safety of Timiryazev machines and equipment. Approved on 2011.10.18. M., 2014. 66

3. (2017) The problem of document quality management of technical products. [electronic resource malfunction] Available: http://www.imash.ru/materials/production/17999-problemakachestva-tekhnicheskojj-produkcii.html (the date of the accuracy of the treatment is September 22, 2017)

4. (2016) GOST R ISO 9001-2015 Federal Agency for Technical Regulation and Metrology National Standard of the Russian
Federation Quality Management System Requirements M.: Standardinform, 2016. 40 p.

5. (2017) Quality Management Systems. Guidance on the application of ISO 9001: 2015 StandardInform, 2017. 15c

6. (2014) Revolyutsiya kachestva: cherez kachestvo reklamnoe ili cherez kachestvo real'noe: monografiya V.T. Prokhorov [i dr.] ; pod obshch. red. d.t.n., prof. V.T. Prokhorova; ISOiP (filial) DGTU. - Novocherkassk: YuRGPU (NPI), 2014. - 384 p.

7. (2015) Reklama kak instrument prodvizheniiya filosofii kachestva proizvodstva konkurentosposobnoy produktsii/ Kompanchenko E.V., [i dr.]; pod obshch. red. d.t.n., prof. V.T. Prokhorova; Institut sfery obsluzhivaniya i predprinimatel'stva (filial) Donskogo gosudarstvennogo tekhnicheskogo universiteta g. Shakhty: ISO i P (filial) DGTU, $2015,-$ p. 623. 